\title{
Signalling and Legitimacy Theories for Explaining Climate Information Disclosure by Russian Companies
}

\author{
Elena Fedorova $\square$ \\ Doctor of Economics, Professor \\ $\underline{\text { ORCID }}$ \\ E-mail: ecolena@mail.ru \\ Department of Corporate Finance and Corporate Governance \\ Financial University under the Government of the Russian Federation, Moscow, Russia
}

\author{
Maria Martynova \\ PhD student \\ $\underline{\text { ORCID }}$ \\ E-mail: mariamartynova95@gmail.com \\ Department of Corporate Finance and Corporate Governance \\ Financial University under the Government of the Russian Federation, Moscow, Russia
}

Journal of Corporate Finance Research, Vol. 15, No. 2, pp. 16-26 (2021)

For citation: Fedorova, Е. и Martynova, M. (2021) «Signalling and Legitimacy Theories for Explaining Climate Information Disclosure by Russian Companies», Journal of Corporate Finance Research / Корпоративные Финансы | ISSN: 2073-0438, 15(2), cc. 16-26. doi: 10.17323/j.jcfr.2073-0438.15.2.2021.16-26.

Received 10 January 2021 | Peer-reviewed 18 January 2021 | Accepted 19 January 2021 


\section{Abstract}

This paper studies the factors influencing the level of climate-related disclosure by Russian companies. It has several distinctive features in comparison to previous works: 1) climate change disclosure by Russian companies is studied for the first time; 2) textual analysis is used to evaluate the level of disclosure, and a new Russian glossary on climate change is compiled; 3) a unique set of indicators is used to assess the impact of factors on climate change disclosure. Legitimacy and signalling theories are used to formulate the hypotheses. The sample consists of 47 Russian companies with the largest market capitalization. Their 235 annual and sustainability reports for 2015-2019 are analysed. Using regression analysis, we show that a company's absolute amount of greenhouse gas emissions, size, industry affiliation, and CDP rating positively affect its level of disclosure about climate change. In contrast, state ownership and a high debt burden have a negative impact. At the same time, the newness of assets, capital expenditures, interest coverage and company growth opportunities have no effect on climate change disclosure. Empirical results have confirmed the applicability of legitimacy theory to the Russian market. The present study will provide investors and regulators with tools for predicting a company's impact on climate based on its level of climate change disclosure.

Key words: climate change, greenhouse gas, information disclosure, textual analysis, signalling theory, legitimacy theory

\section{Introduction}

Climate change is one of the most important challenges facing society today on account of the gravity of its possible consequences: changing weather, natural disasters, falling harvests, sea level rise, growing flood hazard, etc. Climate change is having a global impact of an unprecedented scale on the planet and is bound to affect the international economy. In 2019, extreme weather conditions caused by climate change resulted in global losses of $\$ 100$ billion [1]. By 2050 , cumulative losses from climate change may amount to $\$ 8$ trillion, reducing the global GDP by 3\% [2]. Climate change may have an even more serious impact on the Russian economy: proliferating droughts, floods, forest fires, and permafrost thaw may result in the GDP falling by $3 \%$ even before 2030 [3].

Consequently, a lot of institutional investors take climate-related risks into account when making investment decisions. To this end, they ask companies to disclose climate information [4]. Moreover, a number of central banks and financial regulators have developed a system of requirements for climate-related disclosure to make the evaluation of climate-related risks more accurate. The growing demand for climate-related information encourages companies to consider its disclosure. Still, despite the universality of this trend, the disclosure of such information by companies is inhomogeneous.

The purpose of the present study is to identify the factors that influence the level of climate-related disclosure by Russian companies. It has the following research objectives: 1 ) revealing the theoretical concepts behind corporate information disclosure; 2) analysing previous empirical studies to identify the factors that influence climate-related disclosure in practice; 3 ) compiling a glossary on climate change; 4) analysing annual corporate reports concerning climate-related disclosure using the bag-of-words method; and 5) constructing a regression model to identify the factors of climate-related disclosure.
The present paper has several distinctive features compared to previous works: 1) climate change disclosure by Russian companies is studied for the first time; 2) textual analysis is used to evaluate the level of disclosure, and a Russian glossary of climate change is compiled; 3 ) for the first time, a unique set of indicators is used to assess the impact of factors on climate change disclosure.

\section{Literature Review and Research Hypotheses}

Most academic research has studied factors influencing voluntary information disclosure by companies [5-7]. In addition, many papers have described the factors influencing one of the most important spheres of voluntary information disclosure - environmental data $[8 ; 9]$. Some studies have considered the factors of information disclosure related to the narrower yet not less important problem of climate change [10].

Research literature uses two theories to explain the nature of information disclosure by companies: legitimacy and signalling theories. Legitimacy theory assumes that a company as a social institution operates on the basis of a social contract that ensures its legitimacy [11]. In order to maintain their legitimacy, companies have to observe laws and regulatory requirements as well as complying with ethical standards and societal values [12]. Public information about a company determines how it is perceived by society, and so information disclosure is an important tool for obtaining legitimacy. Company management may use this tool to manage its perception by society if legitimacy is lacking $[11 ; 12]$. The disclosure of information can show that a company is addressing important social problems and trying to facilitate their solution, which may help it to get approval for continuing its activities. The climate change problem is one of the key societal concerns today, which is confirmed by the close attention it gets in public 
corporate materials. In addition, climate-related disclosure may help a company to improve its image for "prolonging the social contract" and reducing the public and regulatory pressure.

Signalling theory asserts that companies disclose information about themselves to send a signal to investors and society in general about their superiority over competitors. Such signals allow companies to distinguish themselves from others and to avoid the problem of adverse selection [13]. Thus, in accordance with signalling theory, climate-related disclosure is an indicator for investors and society in general about climate-related company activities and about company efforts to reduce climate-related risks and climate impact. Climate-related disclosure is an important tool to send signals that would attract investments, enhance reputation and obtain important competitive advantages [13].

Legitimacy and signalling theories offer different explanations for the influence of actual corporate climate impact on the level of information disclosure about this issue. The most frequent type of company climate impact is greenhouse gas emissions [14; 15]. Greenhouse gas emissions, most of which are produced by anthropogenic activity, accumulate in the atmosphere and cause the temperature on the planet to rise [16]. Legitimacy theory presumes that companies with large emissions attract more attention from society and therefore have to disclose more climate-related information in order to reduce public pressure and risks of legitimacy loss [11]. Thus, legitimacy theory predicts a positive relation between the amounts of emissions and climate-related disclosure $[11 ; 12]$. According to signalling theory, companies with less emissions increase information disclosure in order to provide information about their performance to investors and demarcate themselves from companies that have a serious impact on climate [13]. Consequently, signalling theory predicts a negative correlation between the amount of greenhouse gas emissions and the level of climate-related disclosure.

In this paper, we try to use both theories for making hypotheses about the influence of greenhouse gas emissions on climate-related disclosure:

H1a: the amount of greenhouse gas emissions has a positive impact on climate-related disclosure (legitimacy theory).

$H 1 b$ : the amount of greenhouse gas emissions has a negative impact on climate-related disclosure (signalling theory).

Apart from the actual impact produced by a company on the climate, we consider two other qualitative factors which may influence climate-related disclosure - state ownership of company shares and industry affiliation. According to legitimacy theory, state-owned companies should attract greater attention from society and stakeholders, while the management of state-owned companies should be subject to greater control and monitoring. The assumption is that the government is more interested in a high-quality environment than private companies and so will require state-owned companies to disclose more information on this issue $[17 ; 18]$. For this reason, we make the following assumption:
H2: state participation in corporate equity capital has a positive influence on climate-related disclosure.

According to legitimacy theory, companies from industries with the greatest climate impact have to disclose more information in order to improve their social image and justify their activities to society. Oil and gas, electric power, cellulose fibre, chemical, transport and metallurgic companies are considered to have the most negative impact on climate [19]. These companies have greater climate-related risks and spend more money for reducing their influence on the climate. Therefore, they have to disclose more information about themselves in order to enhance transparency, prevent regular inspections and prolong their social contract [20]. This leads to the following hypothesis:

H3: the affiliation of a company with a "polluting" industry has a positive impact on climate-related disclosure.

We also propose to use the Carbon Disclosure Project (CDP) rating as a factor influencing information disclosure. This rating is assigned by an international non-commercial organisation that manages the largest global platform for the disclosure of climate-related information obtained voluntarily from approximately ten thousand companies all over the globe. CDP collects information from companies about their impact on the climate, climatic strategy, corporate governance system and management of climate-related risk. It then employs a sophisticated methodology to assign a rating indicative of the company's efficiency and transparency in the field of climate change. CDP ratings are in high demand among investors: over 500 investors which manage assets amounting to approximately $\$ 106$ trillion require companies to disclose information using the CDP system. It is supposed that companies with high CDP ratings will disclose more information in their reports, because they have already collected, processed and analysed such information. Insofar as they have already made major expenditures on providing information to the CDP, companies with a high rating will not incur a lot of additional costs to disclose climate-related information in their reports. Therefore, we make the following assumption:

H4: companies with a high CDP rating will disclose more climate-related information.

In this study, we also use a series of control variables characterizing corporate financial indicators, including company size, profitability, debt burden, age of assets, capital expenditures, and growth opportunities.

According to legitimacy theory, large companies will use information disclosure in order to legalize themselves in the eyes of society [21]. The assumption is that such companies attract more attention due to their size and therefore have to disclose more information about themselves in order to justify their activities [20]. In addition, measures aimed at reducing their climate impact require significant financial resources. Large companies have more financial opportunities to cover such expenses. As a result, they will disclose more climate-related information because they 
have made greater progress in reducing their impact on the climate.

From the standpoint of legitimacy theory, companies with higher profitability attract greater societal attention to the ways they make their profits. In order to mitigate public pressure and justify their high profitability, such companies have to disclose more information about themselves. This allows them to obtain legitimacy in society.

Companies with a high debt burden attract more attention from creditors, among others. The creditors of a company demand more information in order to assess risks, which explains the higher level of voluntary information disclosure by companies with a bigger debt burden [22].

Newer assets manufactured with the help of advanced technologies tend to release less emissions into the atmosphere [22]. Thus, companies with more advanced equipment produce a smaller negative effect on climate and, as a consequence, disclose more information on their climate impact [23].

Capital expenditures are normally used to purchase new assets or update and modernize old ones, and so companies with high capital expenditures reduce their emissions and disclose climate-related information more willingly [24]. Besides, companies with high capital expenditures disclose more information in order to justify their expenses by demonstrating the reduction of their impact on the climate.

As a company's growth opportunities expand, information asymmetry between managers and investors increases, which complicates the evaluation of the market value of corporate assets [19]. As a result, a company will be keen to reduce information asymmetry by means of a higher level of disclosures [26]. This leads to our next hypothesis:

H5: the financial indicators of a company influence climate-related disclosure, with company size, profitability, debt burden, capital expenditure, and growth opportunities having a positive impact and age of assets having a negative one.

\section{Research Methodology}

Many studies of voluntary information disclosure in the sphere of environment and climate impact use textual analysis as a research method $[5 ; 27 ; 28]$. Most of these papers employ the data of companies from developed economies such as the USA, Canada, Japan, Australia, and the EU, while only a few studies have been dedicated to companies from emerging economies.

In this paper, we also apply textual analysis using the bag-of-words method to assess the level of disclosure by companies. Several glossaries on climate change compiled by major international organisations such as Intergovernmental Panel on Climate Change (IPCC) [29], the UN (the glossary of terms used by the United Nations Framework Convention on Climate Change (UN FCCC) [30]), and the World Bank [31] were used by the authors to make their own glossary of 500 words related to cli- mate. The words in the glossary have been adapted to the Russian language and our research objectives. First of all, we excluded words that are not directly related to climate change (e.g., "risk", "sustainability", and "impact"). Secondly, we translated these words into Russian and added their synonyms. Thirdly, we lemmatized the words (i.e., inflected them up to their lemma or base form [32]) in order to evaluate word frequency correctly and take all possible word forms into account. Special word form vocabularies were used for lemmatization. They helped to inflect search words and the text in which the search was performed. As a result, contextual search can now be used to find search words.

After lemmatization, we calculated the frequency of use of each word in the glossary and then summed it for all the words in the glossary to obtain the overall number of occurrences of words related to climate change in corporate reports. Finally, we normalized the number of occurrences of words from the glossary against the total number of words in the report in order to balance the size differences between corporate reports. As a result, the following formula was used to calculate the endogenous variable (1):

$$
\mathrm{CD}_{\mathrm{ij}}=\frac{\sum \text { Climate }_{\text {words }}}{\text { Words }_{\mathrm{ij}}} \text {, }
$$

where $\mathrm{CD}_{\mathrm{ij}}$ is the normalized number of climate-related words from the glossary that are used in the report;

Climate words ${ }_{\mathrm{ij}}$ is the number of repetitions of each climate-related word from the glossary;

\section{Words $_{\mathrm{ij}}$ is the total number of words in a report.}

We chose the amount of greenhouse gas emissions caused by a company's activities (scope 1 and 2 - direct and indirect energy emissions) measured in tons of $\mathrm{CO}_{2}$-equivalent as the variable responsible for the company's direct impact on the climate. This indicator is very often used by studies to measure company impact on climate [14; 15]. To analyse the influence of this factor on the disclosure level, we used the amount of emissions both in absolute terms $\left(\mathrm{GHG}_{\mathrm{ij}}\right)$ and relative to assets for the purpose of balancing company size $\left(\mathrm{GHG}_{-}\right.$assets $\left._{\mathrm{ij}}\right)$.

Government ownership in corporate equity capital $\left(\mathrm{Gov}_{\mathrm{ij}}\right)$ is expressed as a dummy variable (1 - the state is one of the company owners, 0 - otherwise). The dummy variable $\left(\operatorname{Ind}_{\mathrm{ij}}\right)$ also shows that a company belongs to a polluting industry ( 1 - belongs, 0 - does not belong) such as the oil and gas, mining and metallurgic, electric power, transportation and chemical industries [19]. Companies from other industries such as telecommunications, consumer goods, and real estate have less impact on climate and are therefore considered to be non-polluting industries.

CDP assigns a rating to companies on the basis of the data they provide using a scale from A (highest result) to F (refusal to furnish data). We renumbered this letter-based 
scale in an ordered manner $\left(\mathrm{CDP}_{\mathrm{ij}}\right)$ : an A rating corresponds to 5 points, $\mathrm{B}$ to $4, \mathrm{C}$ to $3, \mathrm{D}$ to $2, \mathrm{E}$ to 1 , and $\mathrm{F}$ to 0 . Many papers use a company's assets to assess its size [11; $22 ; 35]$. In our sample, we used the normal logarithm of this indicator expressed in roubles $\left(\ln _{-}\right.$assets $\left._{\mathrm{ij}}\right)$.

To describe profitability, we used the return on assets (ratio of net profit to assets - $\operatorname{roa}_{\mathrm{ij}}$ ) and the net profit margin (ratio of net profit to revenue - $\operatorname{margin}_{\mathrm{ij}}$ ), just as in other research on similar topics $[33 ; 34]$.

To measure the corporate debt burden, we chose the ratio of debt to assets $\left(\mathrm{DA}_{\mathrm{ij}}\right)$ and the interest coverage (ratio of operating profit to interest payments - Interest_cov ${ }_{\mathrm{ij}}$ ) along the lines of previous studies $[22 ; 34]$.

The age of assets (Assets_age $\mathrm{ij}_{\mathrm{ij}}$ ) was defined as the ratio of the fixed assets on the books net of depreciation to the fixed assets regardless of depreciation. The higher the ratio, the newer the corporate assets [19]. We also made use of the capital expenditure amount (Capex_ rev $_{\mathrm{ij}}$ ) normalized by the company's revenue as in [19].

Previous studies have used Tobin's Q to assess corporate growth opportunities $[19 ; 22 ; 25]$. This coefficient is equal to the ratio of a company's market value to the book value of its assets ( Tobin_ $\mathrm{Q}_{\mathrm{ij}}$ ). An increment in this ratio implies an increase in the company's expected growth opportunities.

All of the above hypotheses were verified by means of regression analysis. The evaluated regression is fully represented by the following formula (2):

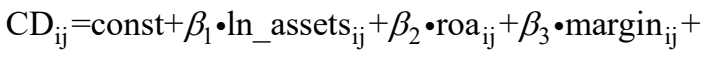

$$
\begin{aligned}
& +\beta_{4} \cdot \mathrm{DA}_{\mathrm{ij}}+\beta_{5} \cdot \text { Interest_cov } \operatorname{cov}_{\mathrm{ij}}+\beta_{6} \cdot \text { Assets_age } \mathrm{ij}_{\mathrm{ij}}+ \\
& +\beta_{7} \cdot \text {Capex_rev }_{\mathrm{ij}}+\beta_{8} \cdot \mathrm{Tobin}_{-} \mathrm{Q}_{\mathrm{ij}}+\beta_{9} \cdot \mathrm{Gov}_{\mathrm{ij}}+\beta_{10} \cdot \mathrm{Ind}_{\mathrm{ij}}+ \\
& +\beta_{11} \cdot \mathrm{GHG}_{\mathrm{ij}}+\beta_{12} \cdot \mathrm{GHG}_{\text {assets }}+\beta_{13} \cdot \mathrm{CDP}_{\mathrm{ij}} \text {, }
\end{aligned}
$$

where const is the intercept term;

$\beta_{i}$ are the regression coefficients;

ln_ assets $_{\mathrm{ij}}$ is the natural logarithm of the assets;

roa $_{\mathrm{ij}}$ is the return on assets;

$\operatorname{margin}_{\mathrm{ij}}$ is the net profit margin;

$\mathrm{DA}_{\mathrm{ij}}$ is the debt per unit assets;

Interest_cov ${ }_{\mathrm{ij}}$ is the ratio of operating profit to interest payments;

Assets_age ${ }_{i j}$ is the ratio of fixed assets net of depreciation to fixed assets with depreciation;

Capex_rev ${ }_{\mathrm{ij}}$ is the capital expenditures per unit revenue;

Tobin_ $\mathrm{Q}_{\mathrm{ij}}$ is Tobin's Q;

$\mathrm{Gov}_{\mathrm{ij}}$ is the government participation in equity capital;

$\mathrm{Ind}_{\mathrm{ij}}$ is the affiliation with a polluting industry;

$\mathrm{GHG}_{\mathrm{ij}}$ is the amount of greenhouse gas emissions;

GHG_assets ${ }_{\mathrm{ij}}$ is the amount of greenhouse gas emissions per unit assets;

$\mathrm{CDP}_{\mathrm{ij}}$ is the company rating assigned by the CDP.

\section{Data Analysis and Research Results}

Our sample was based on the annual and sustainable development reports of 47 Russian companies with the greatest capitalization from 2015 to 2019 . We analysed 235 reports in all.

Figure 1 shows the annual dynamics of the dependent variable $\mathrm{CD}_{\mathrm{ij}}$. Amid the rising interest in climate change, Russian companies increased their levels of climate information disclosure from year to year.

Figure 1. Level of climate information disclosure $\left(\mathrm{CD}_{\mathrm{ij}}\right)$ in 2015-2019

$3.5 \%$

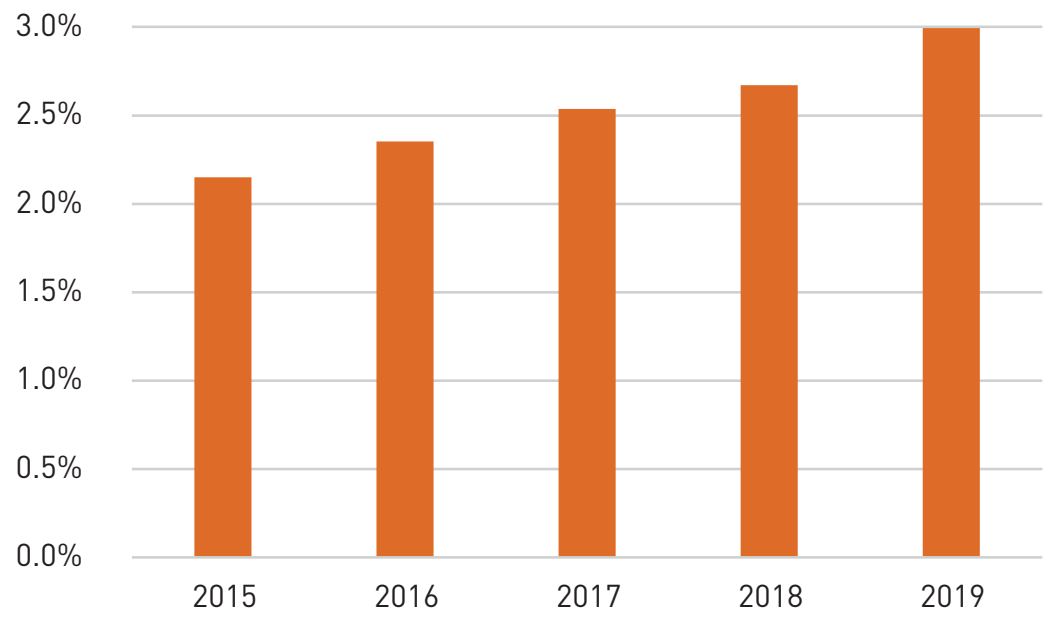

Source: authors' calculations. 
When we broke the companies down by industry, the highest level of climate information disclosure was observed in enterprises from the oil and gas and metallurgic industries
(Figure 2). The lowest level of information disclosure was shown by companies from the chemical and transportation industries.

Figure 2. Average level of climate information disclosure $\left(\mathrm{CD}_{\mathrm{ij}}\right)$ by industry in $2015-2019$

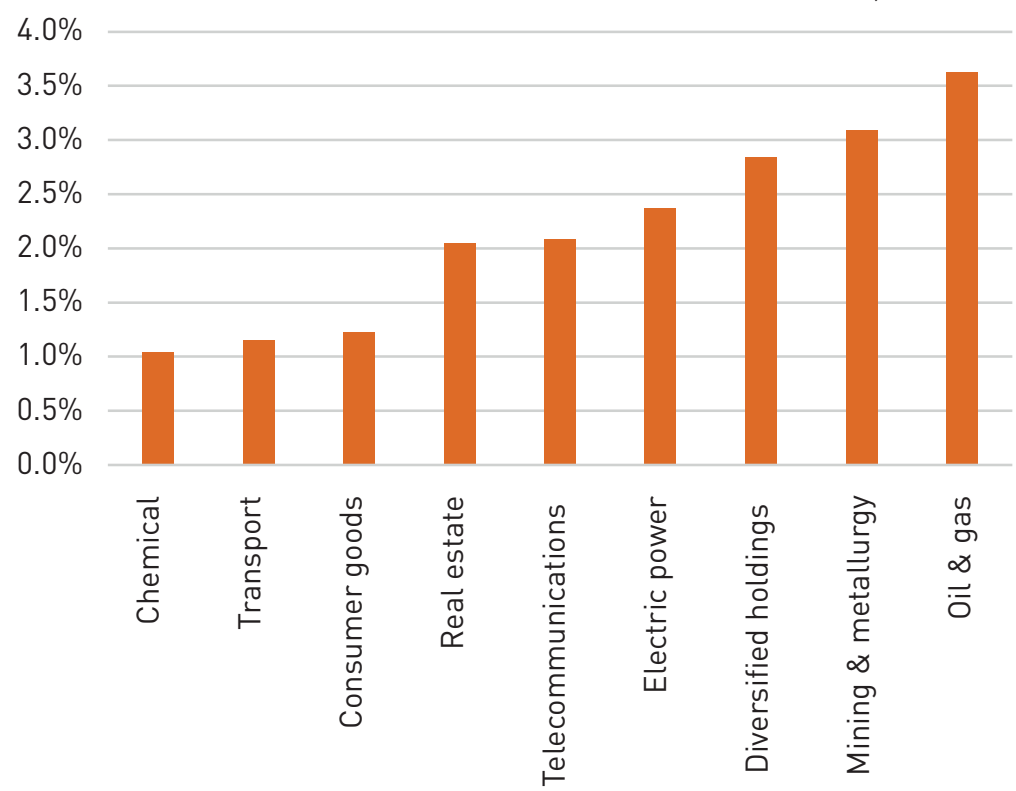

Source: authors' calculations.

When we broke climate information disclosure down by year, it became clear that companies from almost all industries except for transportation increased their level of climate information disclosure in 2019, which shows the growing relevance of this issue for business (Figure 3). In 2015-2019, the greatest progress in climate information disclosure was observed for real estate companies and diversified holdings, which more than tripled their amount of disclosed information. Electric power companies showed a downward trend, reducing their climate information disclosure by $10 \%$.

Figure 3. Level of climate information disclosure $\left(\mathrm{CD}_{\mathrm{ij}}\right)$ by industry in 2015-2019

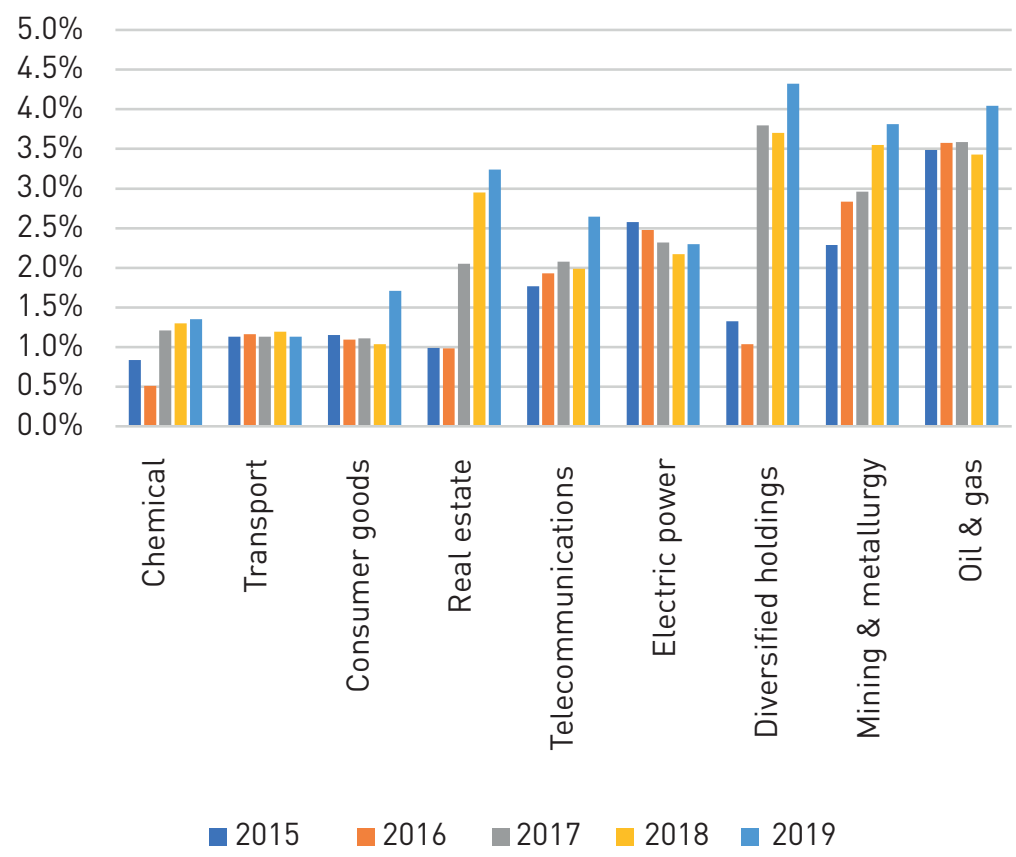

Source: authors' calculations.

In addition, we calculated the semantic distance between the ten most frequent words (phrases) from the authors' climate glossary. Table 1 presents the results of this anal- ysis. The closest semantic distance was found between the words "atmosphere", "emissions", "pollution", "greenhouse gas", and "air". 
Table 1. Semantic distance

\begin{tabular}{|c|c|c|c|c|c|c|c|c|c|c|}
\hline & Atmosphere & Emissions & Pollution & Greenhouse gas & Air & Pollution & Climate & Temperature & Decarbonization & Warming \\
\hline Atmosphere & 1.000 & 0.880 & 0.840 & 0.787 & 0.759 & 0.494 & 0.418 & 0.257 & -0.003 & -0.055 \\
\hline Emissions & 0.880 & 1.000 & 0.829 & 0.911 & 0.786 & 0.520 & 0.476 & 0.224 & -0.068 & 0.091 \\
\hline Pollution & 0.840 & 0.829 & 1.000 & 0.676 & 0.774 & 0.596 & 0.225 & 0.162 & -0.183 & -0.052 \\
\hline Greenhouse gas & 0.787 & 0.911 & 0.676 & 1.000 & 0.682 & 0.493 & 0.579 & 0.176 & 0.053 & 0.177 \\
\hline Air & 0.759 & 0.786 & 0.774 & 0.682 & 1.000 & 0.762 & 0.488 & 0.409 & -0.015 & -0.188 \\
\hline Pollution & 0.494 & 0.520 & 0.596 & 0.493 & 0.762 & 1.000 & 0.500 & 0.410 & 0.038 & -0.114 \\
\hline Climate & 0.418 & 0.476 & 0.225 & 0.579 & 0.488 & 0.500 & 1.000 & 0.186 & 0.155 & 0.284 \\
\hline Temperature & 0.257 & 0.224 & 0.162 & 0.176 & 0.409 & 0.410 & 0.186 & 1.000 & 0.278 & -0.051 \\
\hline Decarbonization & -0.003 & -0.068 & -0.183 & 0.053 & -0.015 & 0.038 & 0.155 & 0.278 & 1.000 & 0.134 \\
\hline Warming & -0.055 & 0.091 & -0.052 & 0.177 & -0.188 & -0.114 & 0.284 & -0.051 & 0.134 & 1.000 \\
\hline
\end{tabular}

Source: authors' calculations.

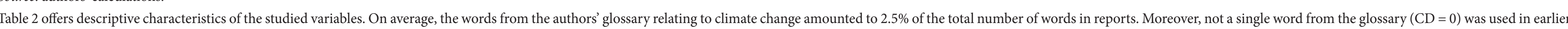

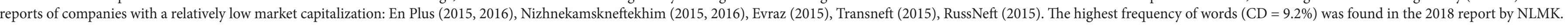

Table 2. Descriptive statistics

\begin{tabular}{|c|c|c|c|c|c|c|}
\hline & Minimum & First quartile & Median & Mean value & Third quartile & Maximum \\
\hline $\mathrm{CD}$ & 0.0000 & 0.01436 & 0.02072 & 0.02541 & 0.03211 & 0.9169 \\
\hline ln_assets & 10.58 & 12.28 & 13.06 & 13.17 & 13.86 & 16.90 \\
\hline Roa & -42.702 & 3.670 & 7.365 & 9.143 & 12.924 & 53.603 \\
\hline margin & -25.882 & 6.045 & 12.388 & 14.631 & 19.073 & 72.381 \\
\hline $\mathrm{DA}$ & 0.0000 & 16.21 & 26.54 & 30.70 & 47.97 & 87.91 \\
\hline Interest_cov & -25.955 & 2.653 & 5.467 & 24.185 & 12.769 & 917.400 \\
\hline Assets_age & 0.2837 & 0.5205 & 0.6275 & 0.6068 & 0.6989 & 1.0000 \\
\hline Capex_rev & 0.007878 & 0.063481 & 0.102331 & 0.125321 & 0.176133 & 0.404211 \\
\hline Tobin_Q & 0.0053 & 0.7541 & 1.1229 & 1.2552 & 1.6234 & 3.3082 \\
\hline Gov & 0.0000 & 0.0000 & 0.0000 & 0.3617 & 1.0000 & 1.0000 \\
\hline Ind & 0.0000 & 0.0000 & 1.0000 & 0.7447 & 1.0000 & 1.0000 \\
\hline GHG & 48.72 & 1301.90 & 5334.50 & 24518.33 & 31215.00 & 239970.00 \\
\hline GHG_assets & 0.1371 & 3.1504 & 9.9166 & 39.6802 & 45.6760 & 402.4594 \\
\hline $\mathrm{CDP}$ & 0.0000 & 0.0000 & 1.000 & 1.113 & 1.000 & 5.000 \\
\hline
\end{tabular}

Source: authors' calculations.

0.0000

1.113

1.000

5.000 
In order to verify the hypotheses, five panel random effect regressions were evaluated with the gradual addition of new regressors. The first model assessed only the influence of emissions in absolute and relative terms $\left(\mathrm{GHG}_{\mathrm{ij}}\right.$ и $\mathrm{GHG}_{\text {_assets }} \mathrm{ij}_{\mathrm{j}}$ ) on the disclosure level $\left(\mathrm{CD}_{\mathrm{ij}}\right)$. It and all its variables turned out to be statistically significant at a 5\% level. The determination coefficient amounted to $20 \%$. The second model included an additional variable indicative of government ownership of a part of a company ( $\operatorname{Gov}_{\mathrm{ij}}$ ), which was also significant at a $5 \%$ level. The determination coefficient rose by one percentage point, amounting to $21 \%$. A variable indicative of the company's affiliation with a polluting industry $\left(\operatorname{Ind}_{\mathrm{ij}}\right)$ was added to the third model. It was statistically significant at a $0 \%$ significance level. The determination coefficient rose by five percentage points to $26 \%$. The fourth model also comprised a variable indicative of the company's CDP rating $\left(\mathrm{CDP}_{\mathrm{ij}}\right)$, which turned out to be statistically significant at a $0 \%$ level. The determination coefficient rose by five percentage points to $28 \%$. At the fifth stage, we added variables characterizing corporate financial indicators $\left(l_{n} \operatorname{assets}_{i j}, \operatorname{roa}_{i j}, \operatorname{margin}_{i j}, D_{i j}\right.$, Interest_cov $\mathrm{ij}_{\mathrm{j}}$, Assets_age $\mathrm{ij}_{\mathrm{j}}$, Capex_rev $\mathrm{rij}_{\mathrm{ij}}$, Tobin_Q $\mathrm{Q}_{\mathrm{ij}}$ ).
In general, this model was statistically significant, as confirmed by the $\mathrm{F}$ statistics. The determination coefficient $\mathrm{R}^{2}$ was at a level of $48 \%$, i.e., about half of the dependent variable dispersion that characterizes the information disclosure level explained by the proposed model. Eight out of 13 variables in the random effect model were significant at least at a $5 \%$ level $\left(\mathrm{GHG}_{\mathrm{ij}}, \mathrm{Gov}_{\mathrm{ij}}\right.$, Ind $\mathrm{In}_{\mathrm{ij}}, \mathrm{CDP}_{\mathrm{ij}}, \ln _{\text {_assets }} \mathrm{ij}$, roa $\mathrm{ij}$, $\left.\operatorname{margin}_{\mathrm{ij}}, \mathrm{DA}_{\mathrm{ij}}\right)$. These variables were included in the final panel regression model, which contained only statistically significant variables. Its determination coefficient amounted to $47 \%$. The Breusch-Pagan test proved the absence of heteroscedasticity of random residuals in the final model.

The panel random effect regression model was chosen because it had the best final indicators. The Hausman test was conducted for evaluation. Its zero hypothesis states that the model factors are exogenous, i.e., we should prefer the random effect model, while the alternative hypothesis states that the factors are endogenous, and thus the fixed effect model is more preferable. The significance value of this test exceeded 0.1 (p-value). So, the zero hypothesis should be accepted, and the random effect model should be chosen. Table 3 shows the characteristics of the considered models.

Table 3. Key characteristics of considered panel regression models with random effect ${ }^{1}$

\begin{tabular}{|c|c|c|c|c|c|c|}
\hline Variable & Model 1 & Model 2 & Model 3 & Model 4 & Model 5 & Model 6 \\
\hline \multicolumn{7}{|c|}{ Emission indicators } \\
\hline GHG & $\begin{array}{c}1.7976 \mathrm{e}-07 \\
(2.3920 \mathrm{e}- \\
08)^{\star * *}\end{array}$ & $\begin{array}{c}2.0115 \mathrm{e}-07 \\
(2.5803 \mathrm{e}- \\
08)^{\star * *}\end{array}$ & $\begin{array}{c}2.0509 \mathrm{e}-07 \\
(2.5149 \mathrm{e}- \\
08)^{\star * *}\end{array}$ & $\begin{array}{c}1.7298 \mathrm{e}-07 \\
(2.5971 \mathrm{e}- \\
08)^{\star * *}\end{array}$ & $\begin{array}{c}7.5713 \mathrm{e}-08 \\
(2.6826 \mathrm{e}-08)^{\star *}\end{array}$ & $\begin{array}{l}7.9639 \mathrm{e}-08 \\
(2.4105 \mathrm{e}-08)^{\star *}\end{array}$ \\
\hline GHG_assets & $\begin{array}{c}-3.5380 e-05 \\
(1.5397 e-05)^{\star}\end{array}$ & $\begin{array}{c}-3.7308 \mathrm{e}-05 \\
(1.5310 \mathrm{e}-05)^{\star}\end{array}$ & $\begin{array}{c}-4.9348 \mathrm{e}-05 \\
(1.5261 \mathrm{e}-05)^{\star *}\end{array}$ & $\begin{array}{c}-3.5897 \mathrm{e}-05 \\
(1.5293 \mathrm{e}-05)^{\star}\end{array}$ & $\begin{array}{c}5.3231 \mathrm{e}-06 \\
(1.6740 \mathrm{e}-05)\end{array}$ & \\
\hline \multicolumn{7}{|c|}{ Control variables } \\
\hline Gov & & $\begin{array}{c}-4.8881 \mathrm{e}-03 \\
(2.3096 \mathrm{e}-03)^{*}\end{array}$ & $\begin{array}{c}-5.2533 \mathrm{e}-03 \\
(2.2512 \mathrm{e}-03)^{\star}\end{array}$ & $\begin{array}{c}-4.8542 \mathrm{e}-03 \\
(2.1940 \mathrm{e}-03)^{\star}\end{array}$ & $\begin{array}{c}-9.0504 \mathrm{e}-03 \\
(2.2640 \mathrm{e}- \\
03)^{\star * *}\end{array}$ & $\begin{array}{l}-9.9303 e-03 \\
(2.0298 e- \\
03)^{\star * *}\end{array}$ \\
\hline Ind & & & $\begin{array}{c}8.6156 \mathrm{e}-03 \\
(2.3349 \mathrm{e}- \\
03)^{\star * *}\end{array}$ & $\begin{array}{c}7.9392 \mathrm{e}-03 \\
(2.2802 \mathrm{e}- \\
03)^{\star * *}\end{array}$ & $\begin{array}{c}6.5101 \mathrm{e}-03 \\
(2.2053 \mathrm{e}-03)^{\star \star}\end{array}$ & $\begin{array}{l}6.4670 \mathrm{e}-03 \\
(2.0396 \mathrm{e}-03)^{\star *}\end{array}$ \\
\hline \multicolumn{7}{|c|}{ Company rating } \\
\hline CDP & & & & $\begin{array}{c}3.2437 \mathrm{e}-03 \\
(8.7563 \mathrm{e}- \\
04)^{\star * *}\end{array}$ & $\begin{array}{c}1.9690 \mathrm{e}-03 \\
(7.9973 \mathrm{e}-04)^{\star}\end{array}$ & $\begin{array}{l}2.1052 \mathrm{e}-03 \\
(7.8449 \mathrm{e}-04)^{\star *}\end{array}$ \\
\hline \multicolumn{7}{|c|}{ Financial indicators } \\
\hline ln_assets & & & & & $\begin{array}{c}6.6864 \mathrm{e}-03 \\
(9.6969 \mathrm{e}- \\
04)^{\star * *}\end{array}$ & $\begin{array}{c}6.4936 \mathrm{e}-03 \\
(8.1747 \mathrm{e}- \\
04)^{\star * *}\end{array}$ \\
\hline
\end{tabular}

${ }^{1}$ The boxes indicate the values of the coefficient in the model and the standard error in parentheses. 


\begin{tabular}{|c|c|c|c|c|c|c|}
\hline Variable & Model 1 & Model 2 & Model 3 & Model 4 & Model 5 & Model 6 \\
\hline \multicolumn{5}{|l|}{ Roa } & $\begin{array}{c}-3.8978 \mathrm{e}-04 \\
(1.6763 \mathrm{e}-04)^{*}\end{array}$ & $\begin{array}{l}-3.4308 \mathrm{e}-04 \\
(1.4153 \mathrm{e}-04)^{*}\end{array}$ \\
\hline \multicolumn{5}{|l|}{ margin } & $\begin{array}{c}3.3871 \mathrm{e}-04 \\
(1.0598 \mathrm{e}-04)^{\star \star}\end{array}$ & $\begin{array}{c}3.3221 \mathrm{e}-04 \\
(9.5679 \mathrm{e}- \\
05)^{\star * \star}\end{array}$ \\
\hline \multicolumn{5}{|l|}{ DA } & $\begin{array}{c}-1.4138 \mathrm{e}-04 \\
(5.1477 \mathrm{e}-05)^{\star *}\end{array}$ & $\begin{array}{l}-1.0418 \mathrm{e}-04 \\
(4.3235 \mathrm{e}-05)^{*}\end{array}$ \\
\hline \multicolumn{5}{|l|}{ Interest_cov } & $\begin{array}{c}-1.4857 \mathrm{e}-05 \\
(1.0708 \mathrm{e}-05)\end{array}$ & \\
\hline \multicolumn{4}{|l|}{ Assets_age } & & $\begin{array}{l}-7.7057 \mathrm{e}-03 \\
(7.7816 \mathrm{e}-03)\end{array}$ & \\
\hline \multicolumn{4}{|l|}{ Capex_rev } & & $\begin{array}{c}6.3467 \mathrm{e}-04 \\
(1.2175 \mathrm{e}-02)\end{array}$ & \\
\hline \multicolumn{4}{|l|}{ Tobin_Q } & & $\begin{array}{c}2.1173 \mathrm{e}-03 \\
(1.8544 \mathrm{e}-03)\end{array}$ & \\
\hline \multirow{2}{*}{\multicolumn{2}{|c|}{$\begin{array}{c}2.2409 \mathrm{e}-02 \\
(1.2755 \mathrm{e}- \\
03)^{\star \star \star}\end{array}$}} & $\begin{array}{c}2.3729 \mathrm{e}-02 \\
(1.4114 \mathrm{e}- \\
03)^{* * *}\end{array}$ & $\begin{array}{c}1.7826 \mathrm{e}-02 \\
(2.1091 \mathrm{e}- \\
03)^{\star * *}\end{array}$ & $\begin{array}{c}1.4830 \mathrm{e}-02 \\
(2.2066 \mathrm{e}- \\
03)^{* * *}\end{array}$ & $\begin{array}{c}-6.3236 \mathrm{e}-02 \\
(1.3538 \mathrm{e}- \\
02)^{\star * \star}\end{array}$ & $\begin{array}{c}-6.4155 \mathrm{e}-02 \\
(1.0352 \mathrm{e}- \\
02)^{* * \star}\end{array}$ \\
\hline & & & & & & \\
\hline R-Squared: & 0.1974 & 0.21267 & 0.25667 & 0.2987 & 0.48112 & 0.47263 \\
\hline
\end{tabular}

Level of statistical significance: 0 “***”; 0.001 “**”; 0.01 “*”; 0.05 “.”; 0.1 “”

Source: authors' calculations.

Thus, regression analysis shows that the climate information disclosure level may be explained by legitimacy theory, confirming the first hypothesis (H1a). Companies with larger emissions in absolute terms attract more attention from society and therefore should disclose more climate-related information in order to reduce public pressure and risks of legitimacy loss. Our results are in line with studies $[11 ; 12]$. It should be noted that, in this case, the amount of emissions normalized against company size proved to be insignificant in our sample. This suggests that the general impact of a company's activities on climate is taken into consideration irrespective of its size. Hypothesis $\mathrm{H} 1 \mathrm{~b}$ is rejected: signalling theory fails to explain climate information disclosure by Russian companies.

Moreover, it is shown (confirming the legitimacy theory) that Russian companies affiliated with polluting industries disclose more climate-related information in order to improve their social image and justify their activities to society. This agrees with our hypothesis (H3) and the results of [19]. Legitimacy theory also explains the higher level of climate information disclosure by large companies. Practice has shown that, due to their size, such companies attract more attention and so have to disclose more information to justify their activities. These results are in line with hypothesis (H5) and the studies [20;27].
Russian companies with a higher CDP rating disclose more information on climate, because they have already collected, processed and analysed such information. This confirms our hypothesis (H4).

At the same time, debt burden and the state ownership of company capital have a negative influence on the level of climate-related disclosure. This disproves hypotheses ( $\mathrm{H} 2)$ and (H5). This may mean that state-owned companies and companies with a high debt burden lack the necessary funds, labour and time resources for collecting, processing and analysing climate-related information, which is still furnished voluntarily. Our findings contradict the studies $[17 ; 18]$.

As to profitability, we found a contradictory result that precludes us from making a definite conclusion: the indicators of the return on assets and the net profit were both statistically significant yet had opposite effects on the dependent variable. Unlike previous research results $[19 ; 22 ; 23]$, no relation between the level climate information disclosure and the coverage of interest payments, the newness of assets, the capital expenditure level and company growth opportunities was found for Russian companies. This partially contradicts our hypothesis (H5). 


\section{Conclusion}

Today, the issue of climate change evokes the ever greater concerns of society due to its possibly irreversible effects on the planet and serious economic losses. For this reason, many investors and regulators across the globe request that companies disclose more information about their climate impact. However, despite the growing requests, climate information disclosure is still non-uniform among companies. Thus, it is important to understand which factors influence disclosure, which is precisely what our paper does for Russian companies.

The factors that increase climate-related disclosure by Russian companies include the amount of greenhouse gas emissions, company size, its affiliation with a polluting industry, and its CDP rating. At the same time, state ownership and a high debt burden discourage a company from disclosing climate-related information.

Our study provides practical tools for identifying the factors influencing the level of climate-related disclosure by Russian companies, which is important for investors, regulators and other stakeholders interested in increasing company transparency about climate impact. In particular, our results may prove useful for investors who choose companies for their portfolios by using the criterion of information transparency about climate impact. They may also be useful for financial regulators defining requirements for non-financial information disclosure.

\section{References}

1. Kramer K., Ware J. Counting the cost. 2019: A year of climate breakdown. London: Christian Aid; 2019. 24 p. URL: https://www.christianaid.org.uk/sites/ default/files/2019-12/Counting-the-cost-2019-reportembargoed-27Dec19.pdf (accessed on 13.03.2021).

2. Resilience to climate change? The Economist. 2019. URL: https://www.eiu.com/public/topical_report.as px? campaignid=climatechange2019\&zid=climatech ange2019\&utm_source=blog\&utm_medium =one_ site\&utm_name=climatechange2019\&utm_ term=announcement\&utm_content=bottom_link (accessed on 13.03.2021).

3. Newlin C., Conley H.A. Climate change will reshape Russia. CSIS: Center for Strategic and International Studies. Jan. 13, 2021. URL: https://www.csis.org/ analysis/climate-change-will-reshape-russia (accessed on 13.03.2021).

4. Mackenzie C., Ascui F. Investor leadership on climate change: An analysis of the investment community's role on climate change, and snapshot of recent investor activity. New York: UN Global Compact Office; 2009. 40 p. URL: https://www.unpri.org/ download? $\mathrm{ac}=5884($ accessed on 13.03.2021).

5. Hossain M., Reaz M. The determinants and characteristics of voluntary disclosure by Indian banking companies. Corporate Social Responsibility and Environmental Management. 2007;14(5):274-288. https://doi.org/10.1002/csr.154

6. Wang K., Sewon O., Claiborne M.C. Determinants and consequences of voluntary disclosure in an emerging market: Evidence from China. Journal of International Accounting, Auditing and Taxation. 2008;17(1):14-30. https://doi.org/10.1016/j. intaccaudtax.2008.01.001

7. Raffournier B. The determinants of voluntary financial disclosure by Swiss listed companies. European Accounting Review. 1995;4(2):261-280. https://doi.org/10.1080/09638189500000016

8. Amran A., Ooi S.K., Mydin R.T., Devi S.S. The impact of business strategies on online sustainability disclosures. Business Strategy and the Environment. 2015;24(6):551-564. https://doi.org/10.1002/bse.1837

9. Braam G.J.M., de Weerd L.U., Hauck M., Huijbregts M.A.J. Determinants of corporate environmental reporting: The importance of environmental performance and assurance. Journal of Cleaner Production. 2016;129:724-734. https://doi. org/10.1016/j.jclepro.2016.03.039

10. de Faria J.A., Andrade J.C.S., da Silva Gomes S.M. The determinants mostly disclosed by companies that are members of the Carbon Disclosure Project. Mitigation and Adaptation Strategies for Global Change. 2018;23(7):995-1018. https://doi. org/10.1007/s11027-018-9785-0

11. Patten D.M. Intra-industry environmental disclosures in response to the Alaskan oil spill: A note on legitimacy theory. Accounting, Organizations and Society. 1992;17(5):471-475. https://doi. org/10.1016/0361-3682(92)90042-Q

12. Deegan C., Rankin M. Do Australian companies report environmental news objectively? An analysis of environmental disclosures by firms prosecuted successfully by the Environmental Protection Authority. Accounting, Auditing \& Accountability Journal. 1996;9(2):50-67. https://doi. org/10.1108/09513579610116358

13. Verrecchia R. Discretionary disclosure. Journal of Accounting and Economics. 1983;5:179-194. https:// doi.org/10.1016/0165-4101(83)90011-3

14. Depoers F., Jeanjean T., Jérôme T. Voluntary disclosure of greenhouse gas emissions: Contrasting the carbon disclosure project and corporate reports. Journal of Business Ethics. 2016;134(3):445-461. https://doi.org/10.1007/s10551-014-2432-0

15. Broadstock D.C., Collins A., Hunt L.C., Vergos K. Voluntary disclosure, greenhouse gas emissions and business performance: Assessing the first decade of reporting. The British Accounting Review. 2018;50(1):48-59. https://doi.org/10.1016/j. bar.2017.02.002 
16. Climate reports. Key findings. United Nations. 2020. URL: https://www.un.org/en/climatechange/science/ key-findings (accessed on 13.03.2021).

17. Eng L.L., Mak Y.T. Corporate governance and voluntary disclosure. Journal of Accounting and Public Policy. 2003;22(4):325-345. https://doi.org/10.1016/ S0278-4254(03)00037-1

18. Cheng E.C.M., Courtenay S.M. Board composition, regulatory regime and voluntary disclosure. The International Journal of Accounting. 2006;41(3):262289. https://doi.org/10.1016/j.intacc.2006.07.001

19. Stanny E., Ely K. Corporate environmental disclosures about the effects of climate change. Corporate Social Responsibility and Environmental Management. 2008;15(6):338-348. https://doi. org/10.1002/csr.175

20. Luo L., Lan Y.-C., Tang Q. Corporate incentives to disclose carbon information: Evidence from the CDP Global 500 report. Journal of International Financial Management \& Accounting. 2012;23(2):93-120. https://doi.org/10.1111/j.1467-646X.2012.01055.x

21. Deegan C. Introduction: The legitimising effect of social and environmental disclosures - a theoretical foundation. Accounting, Auditing \& Accountability Journal. 2002;15(3):282-311. https:// doi.org/10.1108/09513570210435852

22. Clarkson P.M., Li Y., Richardson G.D., Vasvari F.P. Revisiting the relation between environmental performance and environmental disclosure: An empirical analysis. Accounting, Organizations and Society. 2008;33(4-5):303-327. https://doi. org/10.1016/j.aos.2007.05.003

23. Kalu J.U., Buang A., Aliagha G.U. Determinants of voluntary carbon disclosure in the corporate real estate sector of Malaysia. Journal of Environmental Management. 2016;182:519-524. https://doi. org/10.1016/j.jenvman.2016.08.011

24. Clarkson P.M., Overell M.B., Chapple L. Environmental reporting and its relation to corporate environmental performance. Abacus. 2011;47(1):2760. https://doi.org/10.1111/j.1467-6281.2011.00330.x

25. Barth M.E., Kasznik R. Share repurchases and intangible assets. Journal of Accounting and Economics. 1999;28(2):211-241. https://doi. org/10.1016/S0165-4101(99)00020-8

26. Verrecchia R.E. Essays on disclosure. Journal of Accounting and Economics. 2001;32(1-3):97-180. https://doi.org/10.1016/S0165-4101(01)00025-8
27. Freedman M., Jaggi B. Global warming, commitment to the Kyoto protocol, and accounting disclosures by the largest global public firms from polluting industries. The International Journal of Accounting. 2005;40(3):215-232. https://doi.org/10.1016/j. intacc.2005.06.004

28. Luo L., Tang Q., Lan Y. Comparison of propensity for carbon disclosure between developing and developed countries. Accounting Research Journal. 2013;26(1):634. https://doi.org/10.1108/ARJ-04-2012-0024

29. Glossary of terms. IPCC. 2018. URL: https://www. ipcc.ch/site/assets/uploads/2018/03/wg2TARannexB. pdf (accessed on 13.03.2021).

30. Kokorin A.O., Lipka O.N., Sulyandziga R.V. Climate change: The glossary of terms used by UN FCCC. Moscow: WWF Russia; 2015. 92 p. URL: https:// wwf.ru/upload/iblock/509/wwf_glossary_web.pdf (accessed on 13.03.2021). (In Russ.).

31. Glossary of terms and definitions. World Bank Climate Change Knowledge Portal. 2018. URL: https://climateknowledgeportal.worldbank.org/ themes/custom/wb_cckp/resources/data/CCKP_ Glossary_Oct_2018.pdf (accessed on 13.03.2021).

32. Fedorova E., Grishchenko Yu., Demin I., Chernova E. Assessment of the impact of the level of disclosure of mandatory non-financial information in public annual reports on the investment attractiveness of a company. Korporativnye finansy = Journal of Corporate Finance Research. 2020;14(2):22-34. https:// doi.org/10.17323/j.jcfr.2073-0438.14.2.2020.22-34

33. Dawkins C., Fraas J.W. Coming clean: The impact of environmental performance and visibility on corporate climate change disclosure. Journal of Business Ethics. 2011;100(2):303-322. https://doi. org/10.1007/s10551-010-0681-0

34. Lu Y., Abeysekera I. Stakeholders' power, corporate characteristics, and social and environmental disclosure: Evidence from China. Journal of Cleaner Production. 2014;64:426-436. https://doi. org/10.1016/j.jclepro.2013.10.005

35. Ilina Y.B., Berezinets I.V., Orlova A.V. Information disclosure index: The relationship with financial performance. Korporativnye finansy = Journal of Corporate Finance Research. 2009;3(2):28-39. (In Russ.). https://doi.org/10.17323/j.jcfr.20730438.3.2.2009.28-39 